\title{
Baulamycins A and B, Broad-Spectrum Antibiotics Identified as Inhibitors of Siderophore Biosynthesis in Staphylococcus aureus and Bacillus anthracis
}

\author{
Ashootosh Tripathi ${ }^{\dagger, \uparrow}$, Michael M. Schofield ${ }^{\dagger, \ddagger}$, , George E. Chlipala ${ }^{\dagger}$, Pamela J. Schultz $^{\dagger}$, \\ Isaiah Yim $^{\dagger}$, Sean A. Newmister ${ }^{\dagger}$, Tyler D. Nusca ${ }^{\dagger} \neq$, Jamie B. Scaglione ${ }^{\dagger}$, Philip C. Hanna ${ }^{\ddagger}$, \\ Giselle Tamayo-Castillo\#, and David H. Sherman ${ }^{\dagger,}, \S^{*}$, \\ †Life Sciences Institute, University of Michigan, 210 Washtenaw Avenue, Ann Arbor, MI 48109 \\ ‡Department of Microbiology \& Immunology, University of Michigan Medical School, Ann Arbor, \\ Ml 48109 \\ \#Unidad Estrategica de Bioprospección, Instituto Nacional de Biodiversidad (INBio), Santo \\ Domingo de Heredia, Costa Rica \& CIPRONA, Escuela de Química, Universidad de Costa Rica, \\ 2060 San Pedro, Costa Rica \\ §Departments of Medicinal Chemistry and Chemistry, University of Michigan, Ann Arbor, MI \\ 48109
}

\section{Abstract}

Siderophores are high-affinity iron chelators produced by microorganisms and frequently contribute to the virulence of human pathogens. Targeted inhibition of the biosynthesis of siderophores staphyloferrin B of Staphylococcus aureus and petrobactin of Bacillus anthracis hold considerable potential as a single or combined treatment for methicillin-resistant $S$. aureus (MRSA) and anthrax infection, respectively. The biosynthetic pathways for both siderophores involve a nonribosomal peptide synthetase independent siderophore (NIS) synthetase, including SbnE in staphyloferrin B and AsbA in petrobactin. In this study, we developed a biochemical assay specific for NIS synthetases to screen for inhibitors of SbnE and AsbA against a library of marine microbial-derived natural product extracts (NPEs). Analysis of the NPE derived from Streptomyces tempisquensis led to the isolation of the novel antibiotics baulamycins A (BmcA, 6) and $\mathrm{B}(\mathrm{BmcB}, 7)$. BmcA and $\mathrm{BmcB}$ displayed in vitro activity with $\mathrm{IC}_{50}$ values of $4.8 \mu \mathrm{M}$ and 19 $\mu \mathrm{M}$ against SbnE and $180 \mu \mathrm{M}$ and $200 \mu \mathrm{M}$ against AsbA, respectively. Kinetic analysis showed that the compounds function as reversible competitive enzyme inhibitors. Liquid culture studies with $S$. aureus, B. anthracis, E. coli and several other bacterial pathogens demonstrated the capacity of these natural products to penetrate bacterial barriers and inhibit growth of both Grampositive and Gram-negative species. These studies provide proof-of-concept that natural product

\footnotetext{
*Corresponding Author. David H. Sherman, davidhs@umich.edu.

It These authors contributed equally.

ASSOCIATED CONTENT

Supporting Information. Experimental details, 1D and 2D NMR spectral data, MS fragmentation patterns, high throughput screening campaigns, phylogenetic analysis, kinetic analysis, and bioactivity data of 6 and 7 . This material is available free of charge via the Internet at http://pubs.acs.org.
} 
inhibitors targeting siderophore virulence factors can provide access to novel broad-spectrum antibiotics, which may serve as important leads for the development of potent anti-infective agents

\section{Keywords}

high throughput screening; Staphylococcus aureus; Bacillus anthracis; natural product; antibiotic

\section{INTRODUCTION}

The rapid ability of pathogens to develop resistance to antibiotics is endangering the management of a multitude of serious infections. ${ }^{1-3}$ In alarming contrast to the increase of bacterial adaptation to currently marketed drugs, the discovery of novel classes of antimicrobials is on the decline. ${ }^{4}$ Although the majority of pharmaceutical efforts during the past six decades have focused on the synthetic enhancement of a limited set of unique core scaffolds, a more sustainable route to combat antibiotic resistance is the discovery of novel chemical structures possessing unique microbial targets. ${ }^{2,5}$ Iron acquisition mechanisms in particular may represent effective antimicrobial targets that present substantial hurdles to bacterial antibiotic resistance. ${ }^{6}$ Iron is required for growth and survival of bacteria but remains tightly regulated in the mammalian host. Many pathogenic Gram-positive and Gram-negative bacteria utilize virulence-associated siderophores to scavenge iron from this restricted environment and return it to the microbial cell. ${ }^{7}$ Although previous studies have corroborated siderophore biosynthetic enzymes as effective drug targets through the tailoring of established chemical scaffolds, ${ }^{8-11}$ no novel chemical structures have been identified.

In our efforts to identify new structural antibiotic classes with inhibitory activity against siderophore biosynthetic enzymes, we selected the Gram-positive bacteria methicillinresistant Staphylococcus aureus (MRSA) and Bacillus anthracis as model systems. The "superbug" MRSA is a major public health concern, attributed to more than 18,000 deaths a year in the United States. ${ }^{2,12}$ In contrast, the spore-forming microorganism B. anthracis is the causative agent of anthrax. The ability of the bacterium to quickly achieve high concentrations within infected hosts makes it a serious bioterrorism threat, with mortality rates for inhalational infection historically reaching as high as $94 \% .{ }^{13}$

Both pathogens are strongly associated with antimicrobial resistance, ${ }^{14}$ and their siderophore biosynthetic pathways have been extensively characterized. ${ }^{15,16}$ The siderophores staphyloferrin B (2) of S. aureus ${ }^{17-22}$ and petrobactin (5) of B. anthracis $^{23-30}$ in particular have been shown to be critical for survival in iron-limited environments.

The biosynthetic pathways for both siderophores involve a type A nonribosomal peptide synthetase independent siderophore (NIS) synthetase, SbnE (Figure 1A) in staphyloferrin B and AsbA (Figure 1B) in petrobactin. Type A NIS synthetases are a unique class of enzymes found within siderophore biosynthetic pathways of a number of pathogenic bacteria, including Shigella flexneri, Escherichia coli, and Salmonella typhimurium. ${ }^{31,32}$ These enzymes catalyze the condensation of citric acid with either a polyamine or amino alcohol substrate in an ATP-dependent reaction. ${ }^{31,32}$ Since type A NIS synthetases share similar 
catalytic mechanisms and substrate preferences, we sought to identify novel antibiotics against $S$. aureus or $B$. anthracis that could also serve as broad-spectrum antibiotics against other NIS synthetase-containing pathogens.

\section{RESULTS AND DISCUSSION}

\section{High Throughput Screening for Inhibitors of Siderophore Biosynthesis Derived from Natural Product Extracts}

Fueled by the need to identify a new structural class of antibiotics, we selected a marine microbial-derived natural product extract (NPE) library to identify inhibitors of NIS synthetases in S. aureus and B. anthracis. The majority of currently marketed drugs are derived from natural products, ${ }^{33,34}$ and the marine environment in particular is thought to be an underexplored source of novel chemical structures. ${ }^{35} \mathrm{We}$ developed an enzymatic high throughput assay specific to SbnE and AsbA and adapted it to a malachite green reporter system. ${ }^{36-38}$ The assay was then queried against a library of 19,855 marine microbialderived NPEs to identify inhibitors of enzyme activity (Figure 2). The NPEs in this library are primarily from marine-derived microorganisms collected in Costa Rica, Panama, and Papua New Guinea. Screening SbnE and AsbA in parallel limited the number of false positives and provided a convenient method for prioritization of active extracts. Two rounds of screening yielded 33 strains with greater than $70 \%$ inhibition against SbnE at $7.5 \mu \mathrm{g} / \mathrm{mL}$ and 22 strains with extracts showing greater than 50\% inhibition against AsbA at $75 \mu \mathrm{g} / \mathrm{mL}$ (Figure 2). The higher frequency and activity of extracts against $\mathrm{SbnE}$ is likely due to the lower enzyme concentration $5 \mathrm{nM})$ compared to the AsbA (100 nM) utilized in screening. These were the lowest enzyme concentrations for each respective assay that produced a response fit for screening (Figure S2). Low enzyme concentrations were desired to maximize the likelihood of detecting extracts possessing low-abundance bioactive components.

Among active extracts, Streptomyces tempisquensis (Figure S4) was of particular interest due to its high activity against both SbnE (95.9\%) and AsbA (90.2\%) (Figure S3). The strain was originally isolated from sediments collected in Playa Grande, Costa Rica (-8549’39.8”, $\left.10^{\circ} 18^{\prime} 39.8^{\prime \prime}\right)$ near Las Baulas National Marine Park.

\section{Isolation and Structural Elucidation of the Baulamycins (6-7)}

An iterative bioassay guided C18 fractionation (Figure S5) and subsequent RP-18 HPLC purification (Figure S6) yielded two novel bioactive molecules (Figure 3), baulamycins A (BmcA, 6) and B (BmcB, 7), whose structures are consistent with biogenesis from a type I polyketide synthase pathway. BmcA (6) was purified as a light yellow amorphous solid and possesses a molecular formula of $\mathrm{C}_{28} \mathrm{H}_{48} \mathrm{O}_{6}$ as suggested by HRAPCIMS based on $[\mathrm{M}+\mathrm{H}]^{+}$ ion peak at $m / z 481.3530$ (Figure S7). The ${ }^{1} \mathrm{H}$ (Figure S8) and ${ }^{13} \mathrm{C}$ NMR (Figure S9) data, recorded in $\mathrm{CD}_{3} \mathrm{OD}$ indicated the polyketide nature of $\mathbf{6}$ and indicated the presence of at least three hydroxyl group bearing methines with chemical shifts at $\delta 4.47$ (76.5), 4.01 (73.3) and 3.69 (72.5). Further analysis of the ${ }^{1} \mathrm{H}$ NMR spectrum of 6 identified 12 aliphatic protons in the region of $\delta_{\mathrm{H}} 0.95-2.77$ and six methyl groups at $\delta_{\mathrm{H}} 0.77(\mathrm{~d}), 0.83(\mathrm{~d}), 0.86$ (d), 0.88 (d), 1.02 (t) and 1.06 (d). The ${ }^{13} \mathrm{C}$ NMR and HSQCAD spectra (Figure S10) 
revealed the presence of four quaternary carbons at $\delta_{\mathrm{C}} 148.6$ (an aromatic carbon), 159.1 (two chemically equivalent aromatic carbons) and at $\delta_{C} 218.7$ (a carbonyl carbon). The gCOSY (Figure S11) correlations between two equivalent aromatic protons with a signal at $\delta_{\mathrm{H}} 6.33,6.15$ and HMBCAD (Figure S12) correlation between $\delta_{\mathrm{H}} 6.33,6.15$ to the equivalent carbons at $\delta_{C} 159.1,105.9$ and carbon at $\delta_{C} 148.6$ clearly suggested the presence of resorcinol moiety (Table 1). Similarly, the connectivity from C-1 to C-17 was confirmed by an array of COSY and HMBC couplings in both $\mathrm{CD}_{3} \mathrm{OD}$ and DMSO- $\mathrm{d}_{6}$ to construct a 17-carbon aliphatic straight chain with a characteristic carbonyl carbon at $\delta_{\mathrm{C}} 218.7$. In addition, COSY correlation was observed between $\mathrm{H}-1$ and protons at $\mathrm{C}-2$ along with their $\mathrm{HMBC}$ connection to $\mathrm{C}-3$ suggesting an ethyl-ketone terminus for molecule $\mathbf{6}$. Moreover, the COSY and HMBC correlations indicated the branching of aliphatic chain through a methyl group at C-4 $\left(\delta_{\mathrm{H}} 2.77, \delta_{\mathrm{C}} 44.6\right), \mathrm{C}-6\left(\delta_{\mathrm{H}} 1.42, \delta_{\mathrm{C}} 29.1\right), \mathrm{C}-8\left(\delta_{\mathrm{H}} 1.53, \delta_{\mathrm{C}} 30.9\right)$, and $\mathrm{C}-16\left(\delta_{\mathrm{H}} 1.38, \delta_{\mathrm{C}} 26.6\right)$ positions. The position of the hydroxyl group at $\mathrm{C}-11$ and $\mathrm{C}-13$ were consistent with the distinctive ${ }^{1} \mathrm{H}$ and ${ }^{13} \mathrm{C}$ chemical shifts at $\delta_{\mathrm{H}} 3.69, \delta_{\mathrm{C}} 72.5$ and $\delta_{\mathrm{H}}$ $4.01, \delta_{\mathrm{C}} 73.3$, respectively. Furthermore, HMBC showed a correlation from $\mathrm{H}-1$ ' $\left(\delta_{\mathrm{H}} 4.47\right)$ to $\mathrm{C}-2$ ' $\left(\delta_{\mathrm{C}} 148.6\right)$ along with its contiguous COSY correlation to $\mathrm{H}-14\left(\delta_{\mathrm{H}} 1.88\right)$ indicating a branch-point for the aliphatic chain at C-14 through a pendant attachment of 1'(hydroxymethyl)-resorcinol moiety to complete the structure of BmcA (6) (Table 1).

BmcA (6) consists of seven stereocenters with three hydroxyl bearing carbons, three methyl bearing carbons and a 2-methylpropane containing stereocenter. Initial attempts were made to obtain absolute stereochemical information through chemical manipulations for at-least hydroxyl bearing chiral centers. However, the relatively low yield of baulamycins rendered this approach impractical. Therefore, a nondestructive $J$ based configuration analysis $(\mathrm{JBCA})^{39}$ was employed to propose the relative configuration of BmcA (6) ${ }^{40-42} \mathrm{We}$ calculated ${ }^{3} J_{\mathrm{H}-\mathrm{H}},{ }^{2} J_{\mathrm{C}-\mathrm{H}}$, and ${ }^{3} J_{\mathrm{C}-\mathrm{H}}$ values using a combination of phase sensitive double quantum filtered (PS-DQF)-COSY, homonuclear 2D $J$ spectroscopy (HOMO2D $J$ ), gradientand sensitivity-enhanced hetero $(\omega 1)$ half filtered TOCSY (HETLOC-gse) and heteronuclear 2DJ (HET2DJ) spectral analyses (Figures S13-15).

The relative configurations of stereocenters (C11-C13-C14-C1') in 6 established by JBCA are as follows. At the $\mathrm{C} 1{ }^{\prime}-\mathrm{C} 14$ axis, a large coupling constant ${ }^{3} J_{\mathrm{H} 1}{ }^{\prime}-\mathrm{H} 14 \sim 7.2 \mathrm{~Hz}$ and ${ }^{2} J_{\mathrm{Cl}}$ '-H14 $\sim 5.2 \mathrm{~Hz}$, inferred their anti and gauche orientations, respectively ${ }^{39}$ (Figure 4). For the $\mathrm{C} 14-\mathrm{C} 13$ bond, the large ${ }^{3} J_{\mathrm{H} 14-\mathrm{H} 13} \sim 7.7 \mathrm{~Hz}$ suggested anti orientation, which was also supported by the observed ROESY correlations (Figure S15). An additional large ${ }^{2} J_{\mathrm{C} 13-\mathrm{H} 14} \sim 7.0 \mathrm{~Hz}$ was indicative of the gauche orientation between O-13 and H-14 ${ }^{39}$ (Figure 4). Further, we sliced the HOMO2D $J$ spectrum at $\delta_{\mathrm{H}} 4.01(\mathrm{H}-13)$ suggesting a large coupling constant between H13-H12a and a small value between H13-H12b indicative of anti and gauche orientations, respectively (Figure 4). For the C12-C11 moiety, we sliced the HOMO2D $J$ spectrum at $\delta_{\mathrm{H}} 3.69(\mathrm{H}-11)$ to yield ${ }^{3} J_{\mathrm{H} 12 \mathrm{a}-\mathrm{H} 11} \sim 8.0 \mathrm{~Hz}$ and ${ }^{3} J_{\mathrm{H} 12 \mathrm{a}-\mathrm{H} 11} \sim 3.2$ $\mathrm{Hz}$ suggesting anti and gauche orientation, respectively (Figure 4). Furthermore, large coupling constants were recorded for ${ }^{2} J_{\mathrm{C} 11-\mathrm{H} 12 \mathrm{a}} \sim 6.8 \mathrm{~Hz}$ and ${ }^{2} J_{\mathrm{C} 11-\mathrm{H} 12 \mathrm{~b}} \sim 7.2 \mathrm{~Hz}$ clearly indicating gauche orientations between $\mathrm{O}-11$ and $\mathrm{H}-12 \mathrm{a} / \mathrm{H}-12 \mathrm{~b}^{39}$ (Figure 4). Moving down the axis over C11-C10 moiety, large coupling constant between H-11/H-10a, H-11/H10b and $\mathrm{C} 11 / \mathrm{H} 10$ a suggested gauche orientation between $\mathrm{O}-11$ and $\mathrm{H}-10 \mathrm{a}$. Hence, the relative 
configurations at $\mathrm{C} 1^{\prime}, \mathrm{C} 14, \mathrm{C} 13$ and $\mathrm{C} 11$ were proposed as $1^{\prime} R^{*}, 14 S^{*}, 13 R^{*}$ and $11 R^{*}$, respectively (Figure 3).

Establishment of the relative orientation of protons associated with non-chiral C-10 and C-9 was necessary to measure stereochemistry of subsequent chiral carbons (C8-C4). We sliced both HOMO2D $J$ and PS-DQF-COSY spectrum at $\delta_{\mathrm{H}} 1.41,1.39(\mathrm{H}-10 \mathrm{a}, \mathrm{H}-10 \mathrm{~b})$ and $\delta_{\mathrm{H}}$ $1.19,1.33$ (H-10a, H-10b), respectively. The slicing provided large coupling constants between $\mathrm{H}-10 \mathrm{a} / \mathrm{H}-9 \mathrm{~b}$ and small between $\mathrm{H}-10 \mathrm{a} / \mathrm{H}-9 \mathrm{a}$ suggesting anti and gauche orientations, respectively (Figure 5). Correspondingly, for the C9-C8 axis, calculations yielded ${ }^{3} J_{\mathrm{H} 9 \mathrm{~b}-\mathrm{H} 8} \sim 8.5 \mathrm{~Hz}$ (large) and ${ }^{3} J_{\mathrm{H} 9 \mathrm{a}-\mathrm{H} 8} \sim 3.0 \mathrm{~Hz}$ (small) indicating anti and gauche conformations, respectively (Figure 5). Furthermore, the ROESY correlations and small coupling values obtained from ${ }^{3} J_{\mathrm{C} 7-\mathrm{H} 9 \mathrm{a}} \sim 2.0 \mathrm{~Hz}$ and ${ }^{3} J_{\mathrm{C} 7-\mathrm{H} 9 \mathrm{~b}} \sim 2.1 \mathrm{~Hz}$ confirmed the gauche orientations between $\mathrm{C} 7$ and $\mathrm{H}-9 \mathrm{a} / \mathrm{H}-9 \mathrm{~b}$ facilitating assignment of the relative conformation of $\mathrm{H}-9 \mathrm{a}$ and $\mathrm{H}-9 \mathrm{~b}$ at $\mathrm{C} 9$ (Figure 5).

For C9-C8 axis, the observation of a large ${ }^{3} J_{\mathrm{H} 8-\mathrm{H} 9 \mathrm{~b}}(8.5 \mathrm{~Hz})$ and ${ }^{3} J_{\mathrm{C} 19-\mathrm{H} 9 \mathrm{a}}(8.0 \mathrm{~Hz})$ values indicated that $\mathrm{H}-8$ and $\mathrm{H} 9 \mathrm{~b}$ as well as $\mathrm{C}-19$ and $\mathrm{H}-9 \mathrm{a}$ are in the anti orientation. The relative configuration at $\mathrm{C} 8$ was established to be $R^{*}$ according to the ROE between $\mathrm{H}-8$ and H-9a (Figure 5). For the $\mathrm{C} 8 / \mathrm{C} 7$ bond, the relationship of $\mathrm{C} 19 / \mathrm{H}-7 \mathrm{~b}$ was revealed as anti based on a large ${ }^{3} J_{\mathrm{C} 19-\mathrm{H} 7 \mathrm{~b}} \sim 9.0 \mathrm{~Hz}$ value. Another large coupling value $\left({ }^{3} J_{\mathrm{H} 7 \mathrm{a}-\mathrm{H} 8} \sim 13.0 \mathrm{~Hz}\right)$ and corresponding small coupling value between $\mathrm{C} 6$ and $\mathrm{H}-8\left({ }^{3} J_{\mathrm{C} 6-\mathrm{H} 8} \sim-2.4 \mathrm{~Hz}\right)$ led us to assign the relative conformation of $\mathrm{H}-7 \mathrm{a}$ and $\mathrm{H}-7 \mathrm{~b}$ at $\mathrm{C} 7$ (Figure 5). For the $\mathrm{C} 7 / \mathrm{C} 6$ bond, the observation of small coupling values $\left({ }^{3} J_{\mathrm{H} 7 \mathrm{a}-\mathrm{H} 6} \sim 3.0 \mathrm{~Hz}\right.$ and $\left.{ }^{3} J_{7 \mathrm{~b}-\mathrm{H} 6} \sim 3.2 \mathrm{~Hz}\right)$ along with apparent ROE between H-6 and H-7a/H-7b suggested gauche orientation between H-6 and $\mathrm{H}-7 \mathrm{a} / \mathrm{H} 7 \mathrm{~b}$, establishing relative configuration at $\mathrm{C} 6$ as $S^{*}$ (Figure 5).

For $\mathrm{C} 6$ and $\mathrm{C} 5$, a large ${ }^{3} J_{\mathrm{H} 6-\mathrm{H} 5 \mathrm{~b}}$ value $(\sim 13.0 \mathrm{~Hz})$ and small ${ }^{3} J_{\mathrm{H} 6-\mathrm{H} 5 \mathrm{a}}$ value $(\sim 5.0 \mathrm{~Hz})$ revealed that $\mathrm{H}-6 / \mathrm{H}-5 \mathrm{~b}$ and $\mathrm{H}-6 / \mathrm{H}-5$ a possess anti and gauche relationships, respectively. Additionally, small ${ }^{3} J_{\mathrm{C} 4-\mathrm{H} 6} \sim 2.0 \mathrm{~Hz}$ and ${ }^{3} J_{\mathrm{C} 7-\mathrm{H} 5 \mathrm{a}} \sim-1.8 \mathrm{~Hz}$ values as well as observed ROE between $\mathrm{H}-5 \mathrm{a}$ and $\mathrm{H}-6$ revealed the relative conformation of $\mathrm{H}-5 \mathrm{a}$ and $\mathrm{H}-5 \mathrm{~b}$ at $\mathrm{C} 5$ (Figure 5). For the C5/C4 axis, a large ${ }^{3} J_{\mathrm{H} 5 \mathrm{~b}-\mathrm{H} 4} \sim 8.0 \mathrm{~Hz}$ and small ${ }^{3} J_{\mathrm{H} 5 \mathrm{a}-\mathrm{H} 4} \sim 3.2 \mathrm{~Hz}$ coupling values was obtained from HOMO2DJ and PS-DQF-COSY indicating anti and gauche conformations, respectively. In addition, an anti orientation of the $\mathrm{C} 21$ and $\mathrm{H}-5 \mathrm{a}$ atoms was deduced from the large ${ }^{3} J_{\mathrm{C} 21-\mathrm{H} 15 \mathrm{a}} \sim 11.0 \mathrm{~Hz}$ value obtained from HETLOC-gse spectrum. Further, in ROESY spectrum, ROEs between H-5a/H-4, H-4/H-6 and H-6/H-21 was observed. Taking these data into consideration, the relative configuration at $\mathrm{C} 4$ was proved to be $R^{*}$. Therefore, the relative configuration for C10-C4 moiety was anticipated as $8 R^{*}, 6 S^{*}$ and $4 R^{*}$, respectively, in $\operatorname{BmcA}(\mathbf{6})$.

BmcB (7) was isolated by RP-18-HPLC from the same $\mathrm{C} 18$ fraction containing compound 6. The HRESIMS of the molecule provided a molecular formula of $\mathrm{C}_{27} \mathrm{H}_{46} \mathrm{O}_{6}$ showing a [M $+\mathrm{H}]^{+}$ion peak at 467.3171 (Figure S20). Moreover, baulamycin B (7) had high structural similarity to 6 , as evidenced by nearly identical ${ }^{1} \mathrm{H}$ and ${ }^{13} \mathrm{C}$ NMR chemical shifts when measured in $\mathrm{CD}_{3} \mathrm{OD}$ (Table 1). However, it displayed a subtle difference towards the carbonyl terminus, revealing the absence of terminal ethyl protons and substituting with a terminal methyl singlet at $\delta_{\mathrm{H}} 2.18$ in the 1H NMR spectrum of compound 7 (Figure S21). 
The relative stereochemistry from $\mathrm{C} 1$ ' $-\mathrm{C} 10$ and $\mathrm{C} 5-\mathrm{C} 3$ were proposed to be identical to those of 6 on the basis of highly comparable NMR spectroscopy data (Figures S21-25).

Assessment of the in vitro Biological Activity of Compounds against Purified NIS Enzymes

The malachite green-based bioassay was next employed to assess the dose response of novel compounds BmcA (6) and BmcB (7) against purified SbnE and AsbA (Table 2). Both compounds exhibited in vitro bioactivity against $\mathrm{SbnE}$, with $\mathrm{IC}_{50}$ values of $4.8 \mu \mathrm{M}$ and 19 $\mu \mathrm{M}$ for $\mathrm{BmcA}$ and $\mathrm{BmcB}$, respectively (Figure $6 \mathrm{~A}$ ). Inhibition was also observed against AsbA, with $\mathrm{IC}_{50}$ values of $180 \mu \mathrm{M}$ and $200 \mu \mathrm{M}$ for BmcA and BmcB, respectively (Figure $6 \mathrm{~B})$. The significant difference in apparent inhibition is likely due to the different enzyme concentrations used in the dose response assays, $25 \mathrm{nM}$ for SbnE and $100 \mathrm{nM}$ for AsbA (Figure S2). The assays were originally optimized at these enzyme concentrations to maximize the detection of extracts containing low levels of bioactive components during screening.

As a next step to address whether the baulamycins selectively inhibited type A over other NIS synthetase subfamilies, we explored the activity of both compounds against the petrobactin biosynthetic type C NIS synthetase AsbB. While type A NIS synthetases prefer citric acid as a substrate, type $\mathrm{C}$ enzymes generally utilize citric or succinic acid derivatives often found as complex intermediates within their respective siderophore biosynthetic pathways. ${ }^{31}$ In the petrobactin pathway, AsbB catalyzes condensation of a second molecule of spermidine with either $N 8$-citryl-spermidine (3) or N1-(3,4-DHB)-N8-citryl spermidine (4) ${ }^{30}$ Interestingly, recent work in our laboratory also demonstrates AsbB to be more flexible in substrate selection and capable of partial compensation for AsbA activity in vitro. ${ }^{30}$ Despite these findings, dose response studies revealed inhibition against AsbB to be negligible for both BmcA and $\mathrm{BmcB}$ (Figure 6C). These data indicate that both natural products are more potent in vitro against the type A NIS synthetases SbnE and AsbA than the type $\mathrm{C}$ subfamily member AsbB.

\section{Initial Enzyme Mechanism of Inhibition Studies}

To investigate how the more potent of the two compounds, BmcA (6), inhibits SbnE and AsbA enzymatic activity, we monitored NIS synthetase ATP turnover using a previously described 2-amino-6-mercapto-7-methylpurine ribonucleoside (MESG) kinetic pyrophosphate detection assay. ${ }^{43,44}$ These experiments were conducted by varying a single substrate and holding remaining reaction components at a constant saturating level in the presence and absence of inhibitor. The resulting double reciprocal (Lineweaver-Burk) plots confirmed that kinetic parameters closely matched previously reported values for both enzymes against varied citrate concentrations (Table S1). ${ }^{20,30}$ The plots suggested that BmcA inhibits both enzymes in a reversible, competitive manner with respect to citric acid, the corresponding polyamine, and ATP (Figure S26, Table S1). Although kinetic assays were only conducted with BmcA due to its higher potency and availability (obtained in substantially higher yield from Streptomyces tempisquensis), it is reasonable to expect that $\mathrm{BmcB}$ also possesses these inhibition patterns. 
A replot of slopes derived from the Lineweaver-Burk plot versus inhibitor concentration also enabled an initial investigation into the inhibition constants ( $\mathrm{K}_{\mathrm{i}}$ values) for BmcA against both enzymes (Table S1) ${ }^{45}$ Interestingly, the inhibitor constants were lowest for citric acid (SbnE: $50 \mu \mathrm{M}$; AsbA: $110 \mu \mathrm{M}$ ) followed by the polyamine substrate (SbnE: 210 $\mu \mathrm{M}$; AsbA: $170 \mu \mathrm{M}$ ) and ATP (SbnE: $680 \mu \mathrm{M}$; AsbA: $230 \mu \mathrm{M}$ ). This is surprising given the polar nature of citric acid in comparison to the baulamycins. The explanation for this likely depends on the structure and substrate binding sites in the proteins. Although no structural studies have yet been conducted with SbnE or AsbA, the crystal structures of AsbB and the achromobactin type A NIS synthetase in Pectobacterium chrysanthemi have been determined. ${ }^{30,46}$ Both reveal a single binding pocket that houses substrates and intermediates during catalysis. Elucidation of the differences in the structures of SbnE, AsbA, and these other NIS synthetases could shed light on the exact mechanism of inhibition exerted by the baulamycins and their complete lack of activity against AsbB. Efforts to acquire X-ray crystal structures of both SbnE and AsbA in the presence and absence of baulamycin compounds are expected in due course. Additionally, mutagenesis and selection of S. tempisquensis should improve the yield of the baulamycins, enabling a sufficient amount of these molecules for comprehensive kinetic analysis.

\section{Assessment of Biological Activity against Microbial Cultures}

Since siderophore biosynthesis is required for bacterial survival in iron-limited environments, a selective siderophore synthetase inhibitor would be expected to limit growth only under these conditions. Therefore, we monitored bacterial growth in both irondepleted (IDM) and iron-rich (IRM) media conditions in the presence of $\mathbf{6}$ and $\mathbf{7}$. We also conducted live culture studies to demonstrate the ability of both natural products to penetrate bacteria, an established advantage of natural products over many synthetic chemicals. ${ }^{47}$ However, due to the extremely low yield of the baulamycins from S. tempisquensis, experiments could only be completed in duplicate and the following studies represent an initial assessment of microbial culture bioactivity.

BmcA was found to inhibit growth of $S$. aureus (Newman) in both iron-depleted $\left(\mathrm{IC}_{50}=69\right.$ $\mu \mathrm{M})$ and iron-rich $\left(\mathrm{IC}_{50}=86 \mu \mathrm{M}\right)$ conditions, (Figure $6 \mathrm{D}$, Table 3). Similar inhibition was observed with B. anthracis (Sterne 34F2) under iron-depleted $\left(\mathrm{IC}_{50}=110 \mu \mathrm{M}\right)$ and iron-rich $\left(\mathrm{IC}_{50}=120 \mu \mathrm{M}\right.$ ) conditions (Figure $6 \mathrm{E}$, Table 3 ), suggesting possible secondary targets in the cell. In agreement with in vitro findings against purified enzyme, BmcB was significantly less potent against S. aureus (Newman) and B. anthracis (Sterne 34F2) (Figure S27).

We next tested the potency of BmcA against a clinically isolated MRSA strain (USA 300). Similar to S. aureus (Newman) and B. anthracis (Sterne 34F2), BmcA also inhibited MRSA (USA 300) in iron-depleted $\left(\mathrm{IC}_{50}=130 \mu \mathrm{M}\right)$ and iron-rich $\left(\mathrm{IC}_{50}=130 \mu \mathrm{M}\right)$ conditions (Figure 6F, Table 3), again suggesting secondary cellular targets.

Encouraged by the potency of these compounds on $S$. aureus and B. anthracis strains, we also tested inhibition of the more active BmcA on additional microorganisms possessing NIS synthetase siderophore biosynthetic pathways. Aerobactin was the first discovered siderophore to be assembled by an NIS synthetase system. ${ }^{31,48}$ It contributes to the virulence 
of a multitude of bacteria, including E. coli, and multiple species of Salmonella, Yersinia, and Shigella. ${ }^{31,49}$ The pathway involves the type A and C NIS synthetases IucA and IucC, respectively, ${ }^{50,51}$ which share sequence similarity with NIS synthetases found in most other siderophore biosynthetic pathways. ${ }^{31,32}$ Indeed, SbnE and AsbA appear to be relatives of IucA. ${ }^{31,32}$ Furthermore, staphyloferrin B biosynthetic enzyme SbnF and petrobactin biosynthetic enzyme AsbB share sequence similarity with IucC, ${ }^{31,32}$ collectively suggesting that the baulamycins could also inhibit aerobactin-producing bacteria. Thus, we monitored the ability of BmcA to inhibit bacterial growth of the aerobactin-producing Gram-negative strains of Shigella flexneri, E. coli, and Salmonella typhimurium in iron-depleted and ironrich conditions (Figure 6G,H). BmcA inhibited growth of $S$. flexneri and E. coli cultures in iron-depleted conditions (S. flexneri: $\mathrm{IC}_{50}=20 \mu \mathrm{M} ;$ E. coli: $\mathrm{IC}_{50}=4.2 \mu \mathrm{M}$ ) with lower potency in iron-rich conditions ( $S$. flexneri: $\mathrm{IC}_{50}=46 \mu \mathrm{M} ;$ E. coli: $\mathrm{IC}_{50}=150 \mu \mathrm{M}$ ). Although increased potency of BmcA against $E$. coli in IDM suggests that this microbe could possess fewer nonspecific cellular drug targets, additional studies are required to draw any firm conclusions. While BmcA also appeared to inhibit growth of S. typhimurium cultures, the large standard deviations acquired during the assay led us to classify the $\mathrm{IC}_{50}$ as above $1 \mathrm{mM}$ in both iron-depleted and rich conditions (Figure S27). As improved access to baulamycins becomes possible, follow up studies will enable more extensive analysis of its broad-spectrum antibiotic activity.

The current analysis provides an initial assessment of the ability of BmcA to inhibit growth and demonstrates that the molecule is cell permeable. However, inhibition of all target strains under both growth conditions suggests that $\mathrm{BmcA}$ is acting on some additional cellular targets. Indeed, SbnE and AsbA seem to share varying levels of sequence identity with a number of enzymes in $S$. aureus and B. anthracis, including aminoacyl-tRNA synthetases, CoA synthetases, and fatty-acid CoA ligases in addition to critical enzymes involved in cell envelope biogenesis, inhibition of apoptosis, and spore formation (Figure S28).

Finally, the ability of BmcA to inhibit bacterial growth of both Gram-positive and Gramnegative strains (Table 3) classifies it as a broad-spectrum antibiotic. Although BmcB was not included in these experiments due to low production by Streptomyces tempisquensis, the compound is of a comparable size and possesses similar functional groups, suggesting it also could be capable of inhibiting microbial growth and infiltrating the bacteria. On the other hand, the decreased chain length and potency of BmcB suggests that longer terminal carbon chains may be important in future structure-activity relationship (SAR) studies.

\section{CONCLUSION}

We have identified a new structural class of broad-spectrum antibiotics isolated from a marine microbial derived NPE library. BmcA and BmcB inhibit siderophore biosynthesis, a crucial virulence factor associated with iron sequestration in pathogenic bacteria. Although previous studies have validated siderophore biosynthesis as an effective synthetic drug target, ${ }^{8-11}$ the aforementioned study is the first to demonstrate its potential as a target for discovering novel chemical scaffolds. Structurally unique drugs like the baulamycins present hurdles for the bacterial development of antibiotic resistance. High throughput screening for 
natural product inhibitors of virulence factors including those for siderophore biosynthesis, could provide a fresh arsenal of chemical scaffolds to combat drug-resistant pathogens.

The baulamycin natural products represent promising lead structures that can be further manipulated to improve both potency and target selectivity if required. We have illustrated that the compounds are efficacious in vitro and are capable of penetrating bacterial barriers to inhibit growth of cultures, including B. anthracis, MRSA, S. flexneri, and E. coli. The ability of the drug to inhibit growth of both Gram-positive and Gram-negative bacteria suggests its potential use as a broad-spectrum antibiotic. These growth inhibition studies further suggest that the compounds possess multiple targets in the microbial cell. Given the simultaneous decline in antibiotic drug discovery and increase of multi-drug resistant bacteria, the baulamycins may represent an auspicious starting-point for expanding discovery efforts against significant human pathogens.

\title{
Supplementary Material
}

Refer to Web version on PubMed Central for supplementary material.

\section{Acknowledgments}

\begin{abstract}
We thank Martha J. Larsen and Tom McQuade in the Center for Chemical Genomics, Life Sciences Institute, University of Michigan for high throughput screening automation and NPE sample management. We also thank Eugenio Alvarado in the NMR core facility, Department of Chemistry, University of Michigan for assistance with acquiring spectra for stereochemical studies. We also thank Eli Eisman for initial assistance with mass spectrometry, Andrew Lowell for IR spectroscopy and Dr. Masato Koreeda for access to a polarimeter. The $S$. aureus Newman was a generous gift from Dominique Missiakas (University of Chicago). The B. anthracis Sterne 34F2 strain was provided by Phillip Hanna (University of Michigan). The S. typhimurium strain was a donation of Brenda Franklin (University of Michigan). This research was supported by the International Cooperative Biodiversity Groups initiative (U01 TW007404) at the Fogarty International Center, the Great Lakes Regional Center of Excellence for Bio-defense and Emerging Infectious Diseases Research Grant (U54 AI57153), and the Hans W. Vahlteich Professorship (D.H.S.). Additional funding for M.M.S was provided by the National Science Foundation Graduate Research Fellowship Program (1256260). We thank the Technical Office, CONAGEBIO, Ministry of the Environment and Telecommunications, Costa Rica for providing sample collection permits.
\end{abstract}

\section{ABBREVIATIONS}

\author{
MRSA methicillin-resistant S. aureus \\ NIS nonribosomal peptide synthetase independent siderophore \\ NPE natural product extract \\ MESG 2-amino-6-mercapto-7-methylpurine ribonucleoside \\ IDM Iron-depleted media \\ IRM iron-rich media
}

\section{REFERENCES}

1. Andersson DI, Hughes D. FEMS Microbiol. Rev. 2011; 35:901. [PubMed: 21707669]

2. Fischbach, Ma; Walsh, CT. Science. 2009; 325:1089. [PubMed: 19713519]

3. Nathan C. Sci Transl Med. 2012; 4

4. Livermore DM. J. Antimicrob. Chemother. 2011; 66:1941. [PubMed: 21700626] 
5. Moir DT, Opperman TJ, Butler MM, Bowlin TL. Curr. Opin. Pharmacol. 2012; 12:535. [PubMed: 22841284]

6. Quadri LEN. Infect. Disord. Drug Targets. 2007; 7:230. [PubMed: 17897059]

7. Miethke M, Marahiel MA. Microbiol. Mol. Biol. Rev. 2007; 71:413. [PubMed: 17804665]

8. Gupte A, Boshoff HI, Wilson DJ, Neres J, Labello NP, Somu RV, Xing C, Barry CE, Aldrich CC. J. Med. Chem. 2008; 51:7495. [PubMed: 19053762]

9. Ferreras, Ja; Ryu, J-S.; Di Lello, F.; Tan, DS.; Quadri, LEN. Nat. Chem. Biol. 2005; 1:29. [PubMed: 16407990]

10. Neres J, Labello NP, Somu RV, Boshoff HI, Wilson DJ, Vannada J, Chen L, Barry CE, Bennett EM, Aldrich CC. J. Med. Chem. 2008; 51:5349. [PubMed: 18690677]

11. Somu RV, Boshoff H, Qiao C, Bennett EM, Barry CE, Aldrich CC. J. Med. Chem. 2006; 49:31. [PubMed: 16392788]

12. Klevens RM, Morrison Ma, Nadle J, Petit S, Gershman K, Ray S, Harrison LH, Lynfield R, Dumyati G, Townes JM, Craig AS, Zell ER, Fosheim GE, McDougal LK, Carey RB, Fridkin SK. JAMA. 2007; 298:1763. [PubMed: 17940231]

13. Sweeney DA, Hicks CW, Cui X, Li Y, Eichacker PQ. Am. J. Respir. Crit. Care Med. 2011; 184:1333. [PubMed: 21852539]

14. As defined by the US Center for Disease Control, see: http://www.cdc.gov/drugresistance/ diseasesconnectedar.html

15. Haley KP, Skaar EP. Microbes Infect. 2012; 14:217. [PubMed: 22123296]

16. Hotta K, Kim C-Y, Fox DT, Koppisch AT. Microbiology (Reading, U.K.). 2010; 156:1918.

17. Haag H, Fiedler HP, Meiwes J, Drechsel H, Jung G, Zähner H. FEMS Microbiol. Lett. 1994; 115:125. [PubMed: 8138126]

18. Drechsel H, Freund S, Nicholson G, Haag H, Jung O, Zahner H, Jung G. Biometals. 1993; 6:185. [PubMed: 8400765]

19. Dale SE, Doherty-Kirby A, Lajoie G, Heinrichs DE. Infect. Immun. 2004; 72:29. [PubMed: 14688077]

20. Cheung J, Beasley FC, Liu S, Lajoie GA, Heinrichs DE. Mol. Microbiol. 2009; 74:594. [PubMed: 19775248]

21. Cheung J, Murphy MEP, Heinrichs DE. Chem. Biol. 2012; 19:1568. [PubMed: 23261600]

22. Beasley FC, Cheung J, Heinrichs DE. BMC Microbiol. 2011; 11:199. [PubMed: 21906287]

23. Cendrowski S, MacArthur W, Hanna P. Mol. Microbiol. 2004; 51:407. [PubMed: 14756782]

24. Koppisch AT, Browder CC, Moe AL, Shelley JT, Kinkel BA, Hersman LE, Iyer S, Ruggiero CE. Biometals. 2005; 18:577. [PubMed: 16388397]

25. Lee JY, Janes BK, Passalacqua KD, Pfleger BF, Bergman NH, Liu H, Håkansson K, Somu RV, Aldrich CC, Cendrowski S, Hanna PC, Sherman DH. J. Bacteriol. 2007; 189:1698. [PubMed: 17189355]

26. Pfleger BF, Lee JY, Somu RV, Aldrich CC, Hanna PC, Sherman DH. Biochemistry. 2007; 46:4147. [PubMed: 17346033]

27. Pfleger BF, Kim Y, Nusca TD, Maltseva N, Lee JY, Rath CM, Scaglione JB, Janes BK, Anderson EC, Bergman NH, Hanna PC, Joachimiak A, Sherman DH. Proc. Natl. Acad. Sci. U. S. A. 2008; 105:17133. [PubMed: 18955706]

28. Oves-Costales D, Kadi N, Fogg MJ, Song L, Wilson KS, Challis GL. J. Am. Chem. Soc. 2007; 129:8416. [PubMed: 17579415]

29. Fox DT, Hotta K, Kim C-Y, Koppisch AT. Biochemistry. 2008; 47:12251. [PubMed: 18975921]

30. Nusca TD, Kim Y, Maltseva N, Lee JY, Eschenfeldt W, Stols L, Schofield MM, Scaglione JB, Dixon SD, Oves-Costales D, Challis GL, Hanna PC, Pfleger BF, Joachimiak A, Sherman DH. J. Biol. Chem. 2012; 287:16058. [PubMed: 22408253]

31. Oves-Costales D, Kadi N, Challis GL. Chem. Commun. (Cambridge, U.K.). 2009; 43:6530.

32. Challis GL. Chembiochem. 2005; 6:601. [PubMed: 15719346]

33. Newman DJ, Cragg GM. J. Nat. Prod. 2007; 70:461. [PubMed: 17309302]

34. Newman DJ, Cragg GM. J. Nat. Prod. 2012; 75:311. [PubMed: 22316239] 
35. Montaser R, Luesch H. Future Med Chem. 2012; 3:1475. [PubMed: 21882941]

36. Itaya K, Ui M. Clin. Chim. Acta. 1966; 14:361. [PubMed: 5970965]

37. Pegan SD, Tian Y, Sershon V, Mesecar AD. Comb. Chem. High Throughput Screening. 2010; 13:27.

38. McQuade TJ, Shallop AD, Sheoran A, Delproposto JE, Tsodikov OV, Garneau-Tsodikova S. Anal. Biochem. 2009; 386:244. [PubMed: 19135023]

39. Matsumori N, Kaneno D, Murata M, Nakamura H, Tachibana K. J. Org. Chem. 1999; 64:866. [PubMed: 11674159]

40. Morinaka BI, Molinski TF. Org. Lett. 2011; 13:6338. [PubMed: 22087509]

41. Huang S-X, Wang X-J, Yan Y, Wang J-D, Zhang J, Liu C-X, Xiang W-S, Shen B. Org. Lett. 2012; 14:1254. [PubMed: 22332843]

42. Peng J, Place AR, Yoshida W, Anklin C, Hamann MT. J. Am. Chem. Soc. 2010; 132:3277. [PubMed: 20155901]

43. Webb MR. Proc. Natl. Acad. Sci. U. S. A. 1992; 89:4884. [PubMed: 1534409]

44. Wilson DJ, Aldrich CC. Anal. Biochem. 2010; 404:56. [PubMed: 20450872]

45. Brandish PE, Kimura KI, Inukai M, Southgate R, Lonsdale JT, Brandish PE, Kimura K-i, Inukai M, Southgate R, Lonsdale JT, Bugg TDH. Antimicrob. Agents Chemother. 1996

46. Schmelz S, Botting CH, Song L, Kadi NF, Challis GL, Naismith JH. J. Mol. Biol. 2011; 412:495. [PubMed: 21835184]

47. Roemer T, Xu D, Singh SB, Parish Ca, Harris G, Wang H, Davies JE, Bills GF. Chem. Biol. 2011; 18:148. [PubMed: 21338914]

48. Gibson F, Magrath DI. Biochim. Biophys. Acta. 1969; 192:175. [PubMed: 4313071]

49. Warner PJ, Williams PH, Bindereif A, Neilands JB. Infect. Immun. 1981; 33:540. [PubMed: 6456229]

50. de Lorenzo V, Neilands JB. J. Bacteriol. 1986; 167:350. [PubMed: 3087960]

51. de Lorenzo V, Bindereif A, Paw BH, Neilands JB. 1986; 165:570. 

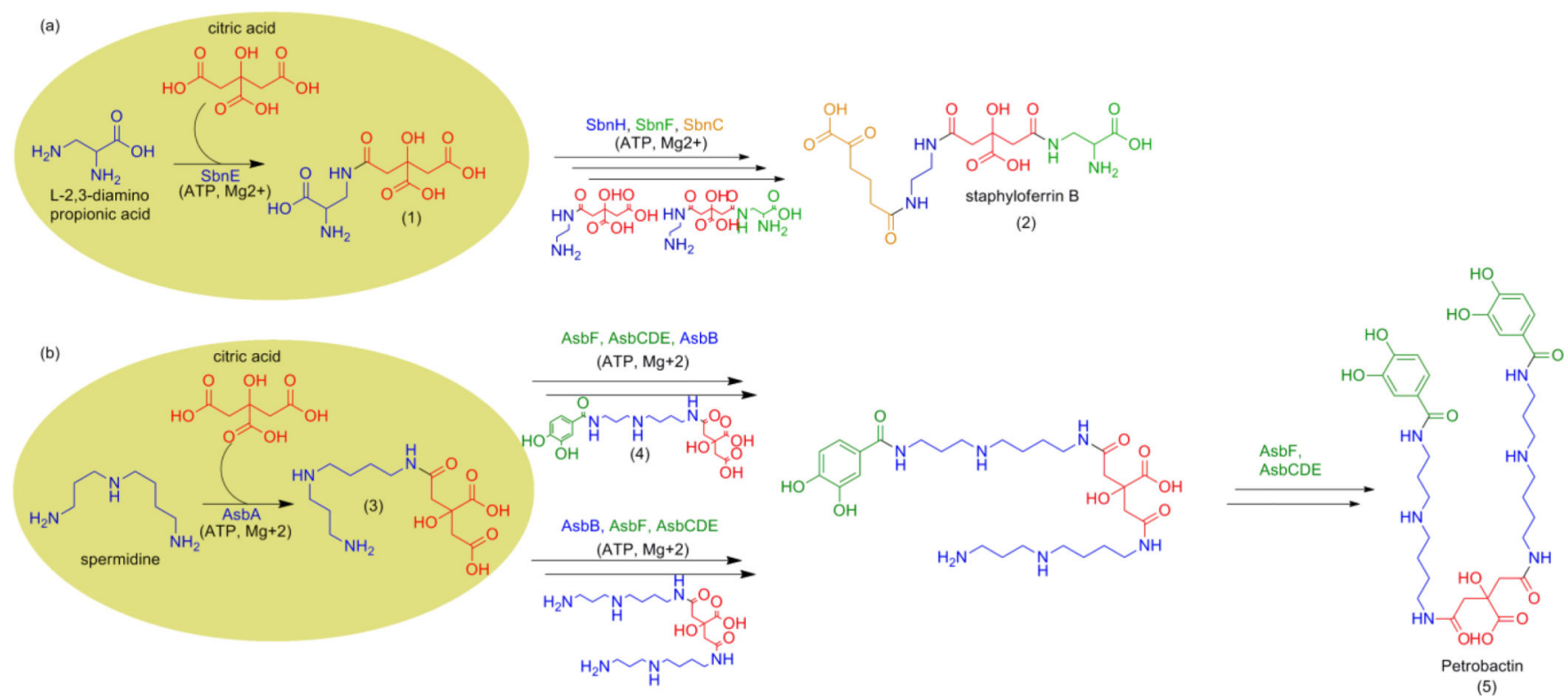

Figure 1.

Biosynthesis of the virulence-associated siderophore (A) staphyloferrin B in S. aureus $(\mathbf{B})$ petrobactin in B. anthracis. Target biosynthetic enzymes SbnE and AsbA are highlighted by the yellow circles. 


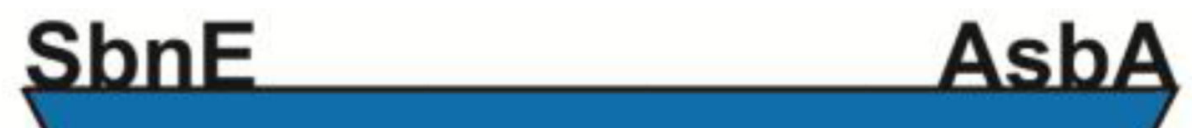

(1) $\geq 90 \%$ Inhibition or

(2) $\geq 70 \%$ inhibition $+10 \%$

\section{Natural Product Extracts:} AsbA inhibition

$\geq 70 \%$ Inhibition at $7.5 \mu \mathrm{g} / \mathrm{mL}$
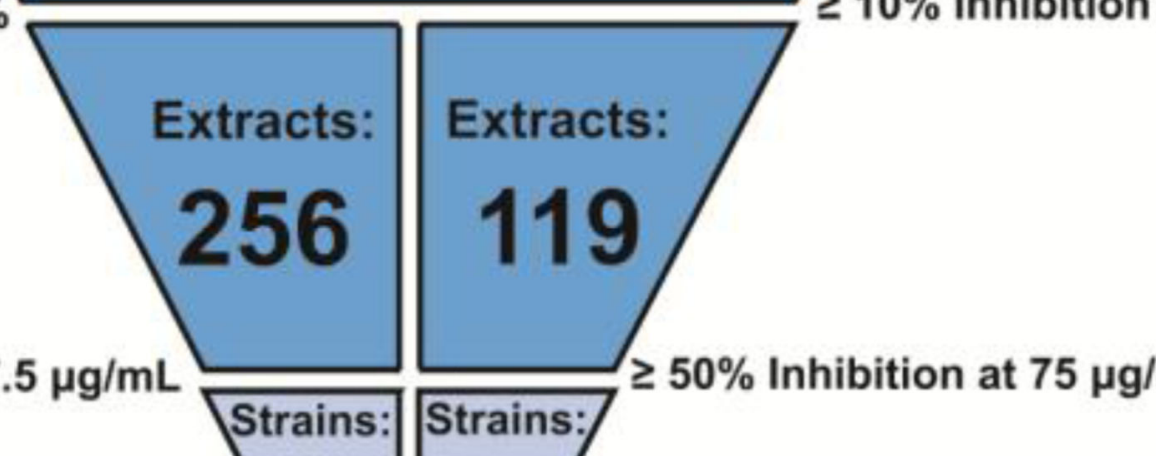

$50 \%$ Inhibition at $75 \mu \mathrm{g} / \mathrm{mL}$

Figure 2.

Triage of hits derived during high throughput screening of SbnE and AsbA against the full microbial NPE library. 

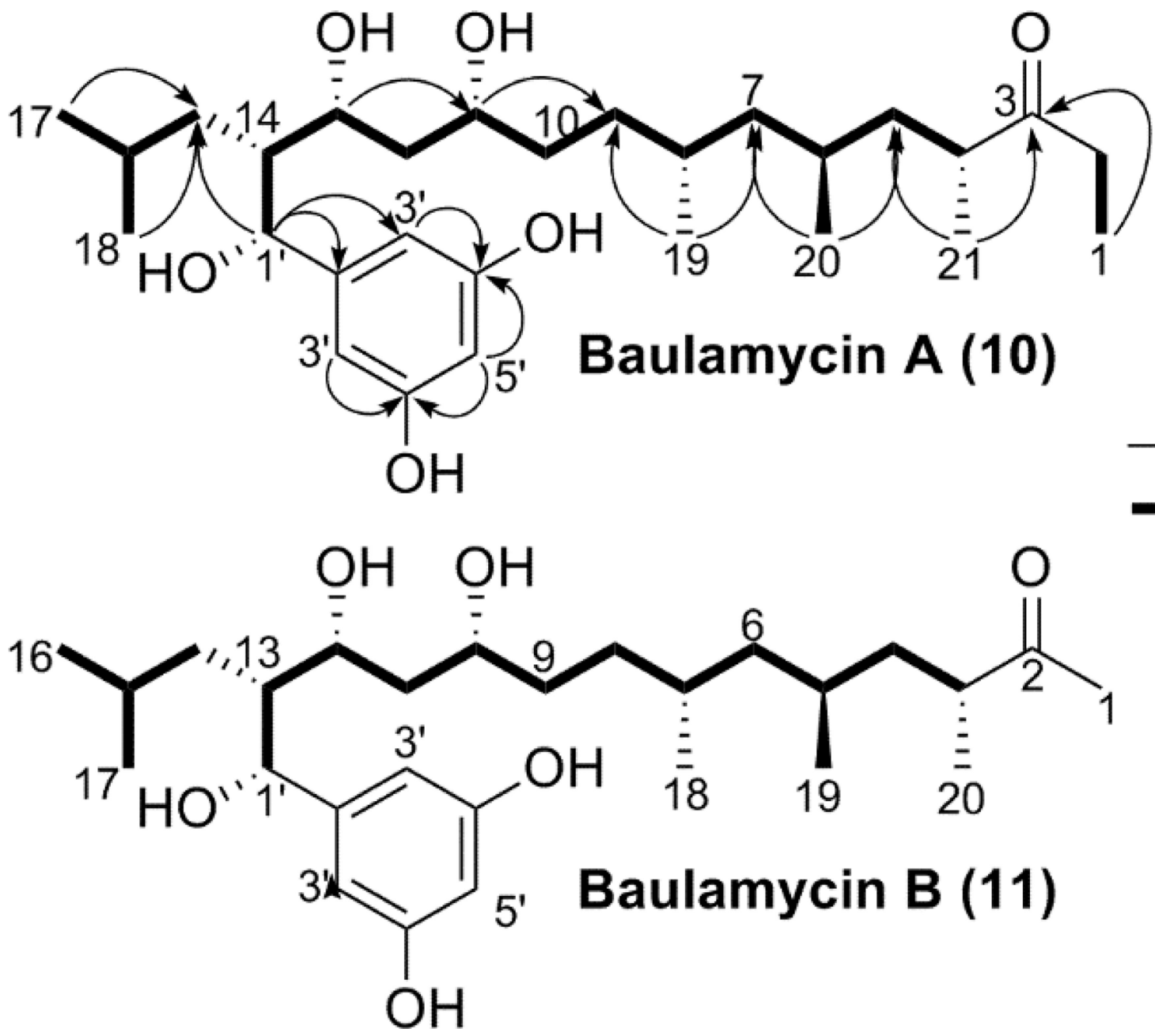

Figure 3.

Planar structure of baulamycins A (6) and B (7) showing COSY correlation with bold bonds and $\mathrm{HMBC}$ correlations with arrow. 


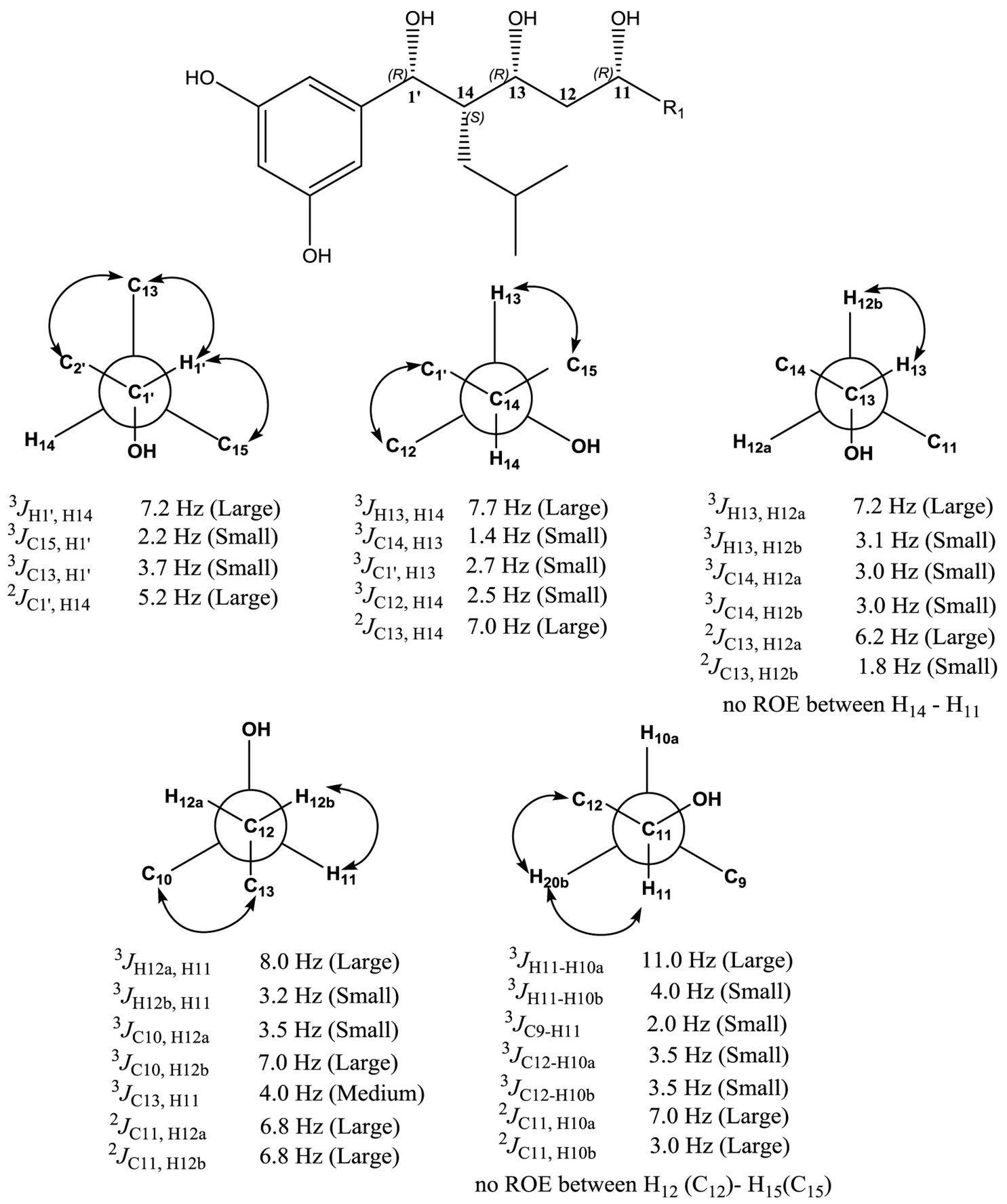

Figure 4.

$\mathrm{H}-\mathrm{H}, \mathrm{C}-\mathrm{H}$ coupling values and relative configuration determined for $\mathrm{C} 1$ '-C11. Arrows showing ROESY correlations. 


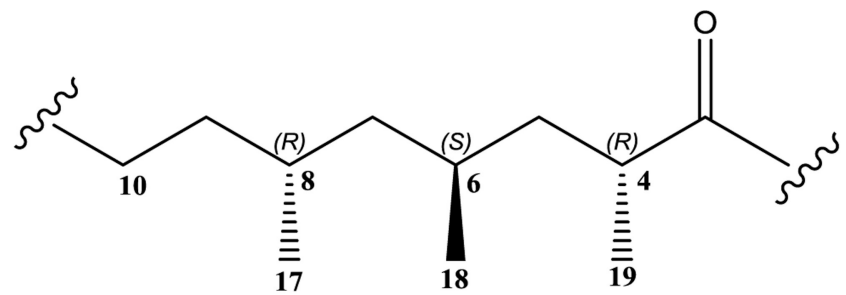

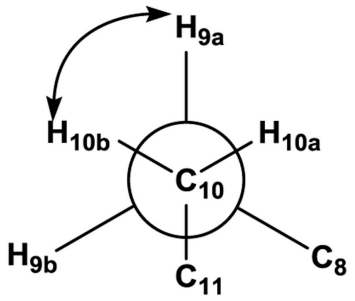

${ }^{3} J_{\mathrm{H} 10 \mathrm{a}-\mathrm{H} 9 \mathrm{~b}}$

${ }^{3} J_{\mathrm{H} 10 \mathrm{~b}-\mathrm{H} 9 \mathrm{a}}$

$9.0 \mathrm{~Hz}$ (Large)

$3.0 \mathrm{~Hz}$ (Small)

${ }^{3} J_{\mathrm{C} 11-\mathrm{H} 9 \mathrm{a}}$

${ }^{3} J_{\mathrm{C} 8-\mathrm{H} 10 \mathrm{a}}$

${ }^{3} J_{\mathrm{C} 11-\mathrm{H} 9 \mathrm{~b}}$

${ }^{3} J_{\mathrm{C} 8-\mathrm{H} 10 \mathrm{~b}}$
$2.0 \mathrm{~Hz}$ (Small)

$2.4 \mathrm{~Hz}$ (Small)

$7.7 \mathrm{~Hz}$ (Large)
$8.0 \mathrm{~Hz}$ (Large)

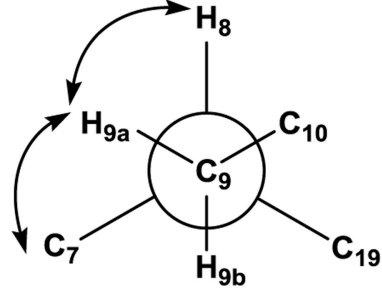

${ }^{3} J_{\mathrm{H} 8-\mathrm{H} 9 \mathrm{~b}} \quad 8.5 \mathrm{~Hz}$ (Large)

${ }^{3} J_{\mathrm{H} 8-\mathrm{H} 9 \mathrm{a}} \quad 3.0 \mathrm{~Hz}$ (Small)

${ }^{3} J_{\mathrm{C} 7-\mathrm{H} 9 \mathrm{a}} \quad 2.0 \mathrm{~Hz}$ (Small)

${ }^{3} J_{\mathrm{C} 7-\mathrm{H} 9 \mathrm{~b}} 2.1 \mathrm{~Hz}$ (Small)

${ }^{3} J_{\mathrm{C} 19-\mathrm{H} 9 \mathrm{a}} \quad 8.0 \mathrm{~Hz}$ (Large)

${ }^{3} J_{\mathrm{C} 19-\mathrm{H} 9 \mathrm{~b}} \quad 3.2 \mathrm{~Hz}$ (Small)

${ }^{3} J_{\mathrm{C} 10-\mathrm{H} 8} \quad 3.0 \mathrm{~Hz}$ (Small)

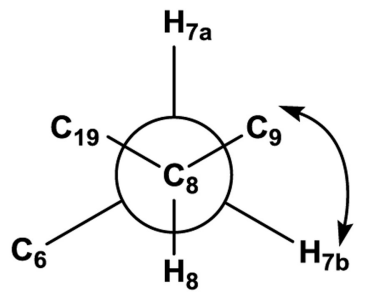

${ }^{3} J_{\mathrm{H} 8-\mathrm{H} 7 \mathrm{~b}}$

${ }^{3} J_{\mathrm{H} 8-\mathrm{H} 7 \mathrm{a}}$

${ }^{3} J_{\mathrm{C} 9-\mathrm{H} 7 \mathrm{a}}$

${ }^{3} J_{\mathrm{C} 9-\mathrm{H} 7 \mathrm{~b}}$

${ }^{3} J_{\mathrm{C} 19-\mathrm{H} 7 \mathrm{~b}}$ ${ }^{3} J_{\mathrm{C} 6-\mathrm{H} 8}$
$5.0 \mathrm{~Hz}$ (Small)

$13.0 \mathrm{~Hz}$ (Large)

$4.7 \mathrm{~Hz}$ (Small)

$4.5 \mathrm{~Hz}$ (Small)

$9.0 \mathrm{~Hz}$ (Large)

$-2.4 \mathrm{~Hz}$ (Small)

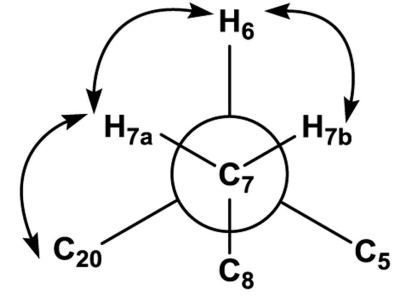

${ }^{3} J_{\mathrm{H} 7 \mathrm{a}-\mathrm{H} 6}$

${ }^{3} J_{\mathrm{H} 7 \mathrm{~b}-\mathrm{H} 6}$

${ }^{3} J_{\mathrm{C} 8-\mathrm{H} 6}$

${ }^{3} J_{\mathrm{C} 5-\mathrm{H} 7 \mathrm{a}}$

${ }^{3} J_{\mathrm{C} 20-\mathrm{H} 7 \mathrm{a}}$

\begin{abstract}
$3.2 \mathrm{~Hz}$ (Small) $3.0 \mathrm{~Hz}$ (Small) $9.0 \mathrm{~Hz}$ (Large) $9.0 \mathrm{~Hz}$ (Large) $2.5 \mathrm{~Hz}$ (Large)
\end{abstract}

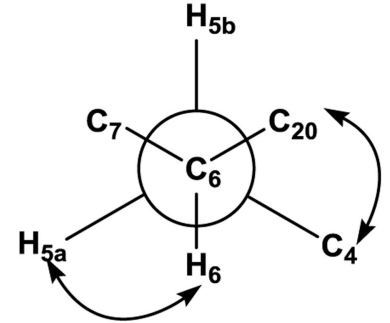

${ }^{3} J_{\mathrm{H} 6-\mathrm{H} 5 \mathrm{a}}$

$5.0 \mathrm{~Hz}$ (Small)

${ }^{3} J_{\mathrm{H} 6-\mathrm{H} 5 \mathrm{~b}}$

$13.0 \mathrm{~Hz}$ (Large)

${ }^{3} J_{\mathrm{C} 4-\mathrm{H} 6}$

$2.0 \mathrm{~Hz}$ (Small)

${ }^{3} J_{\mathrm{C} 7-\mathrm{H} 5 \mathrm{a}}$

$-1.8 \mathrm{~Hz}$ (Small)

${ }^{3} J_{\mathrm{C} 7-\mathrm{H} 5 \mathrm{~b}}$

${ }^{3} J_{\mathrm{C} 20-\mathrm{H} 5 \mathrm{a}}$

$2.2 \mathrm{~Hz}$ (Small)

$8.7 \mathrm{~Hz}$ (Small)

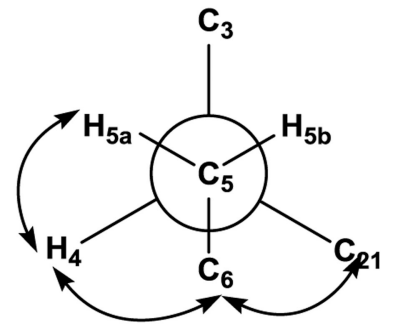

${ }^{3} J_{\mathrm{H} 5 \mathrm{a}-\mathrm{H} 4} \quad 3.2 \mathrm{~Hz}$ (Small)

${ }^{3} J_{\mathrm{H} 5 \mathrm{~b}-\mathrm{H} 4} \quad 8.0 \mathrm{~Hz}$ (Large)

${ }^{3} J_{\mathrm{C} 6-\mathrm{H} 4} \quad-2.0 \mathrm{~Hz}$ (Small)

${ }^{3} J_{\mathrm{C} 21-\mathrm{H} 5 \mathrm{a}} \quad 11.0 \mathrm{~Hz}$ (Large)

${ }^{3} J_{\mathrm{C} 21-\mathrm{H} 5 \mathrm{~b}} \quad 4.0 \mathrm{~Hz}$ (Small)

Figure 5.

$\mathrm{H}-\mathrm{H}, \mathrm{C}-\mathrm{H}$ coupling values and relative configuration determined for C10-C4. Arrows showing ROESY correlations. 
A)

C)
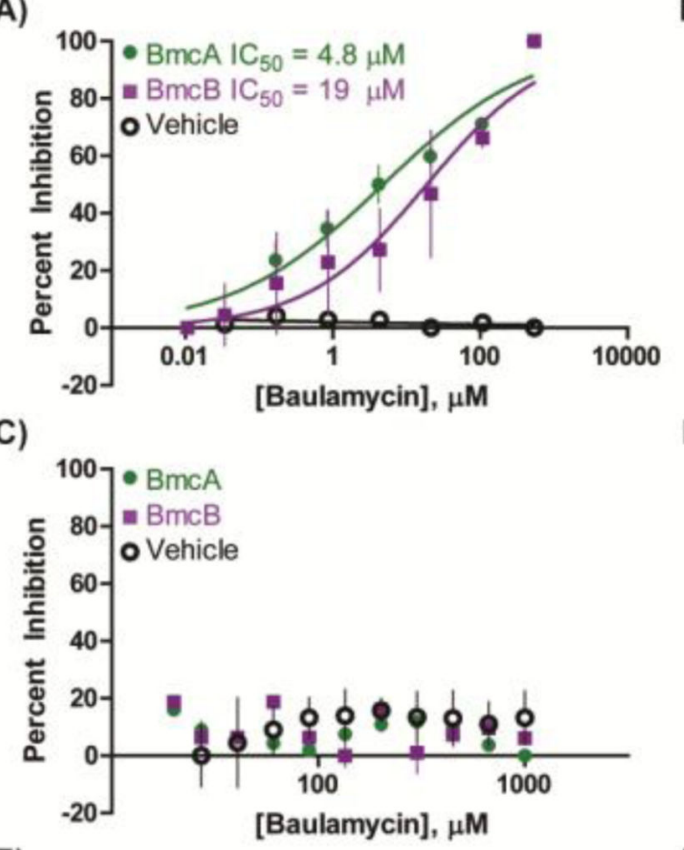

E)

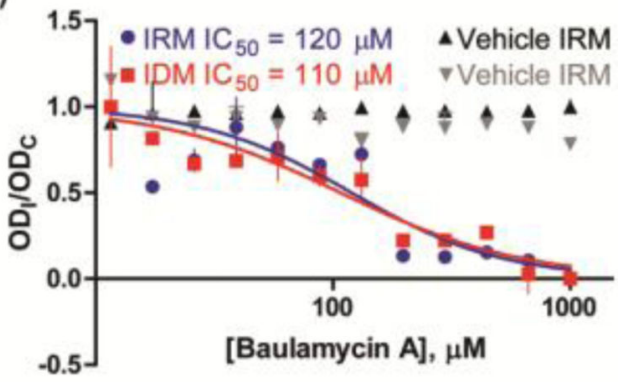

G)

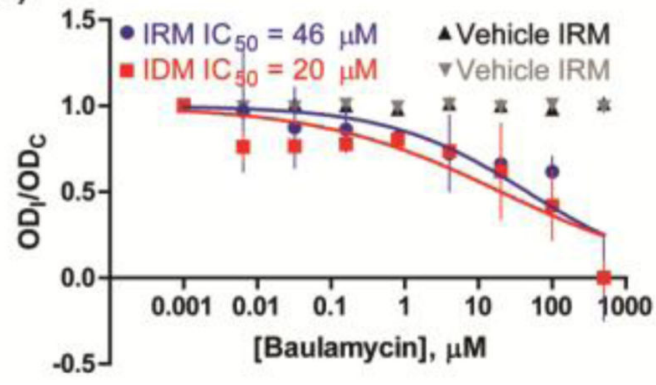

B)

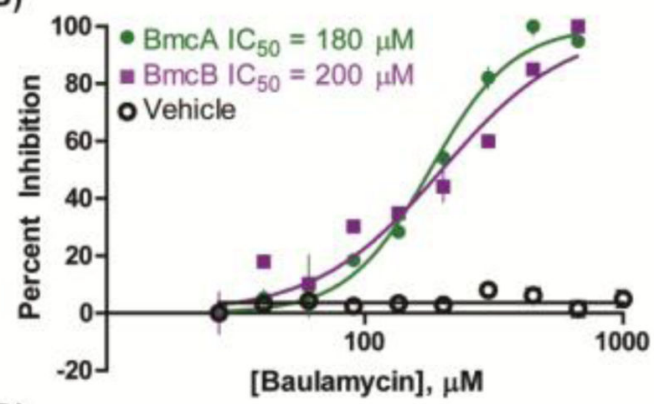

D)

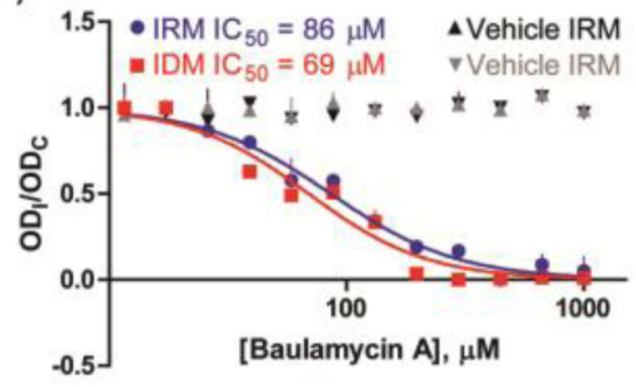

F)

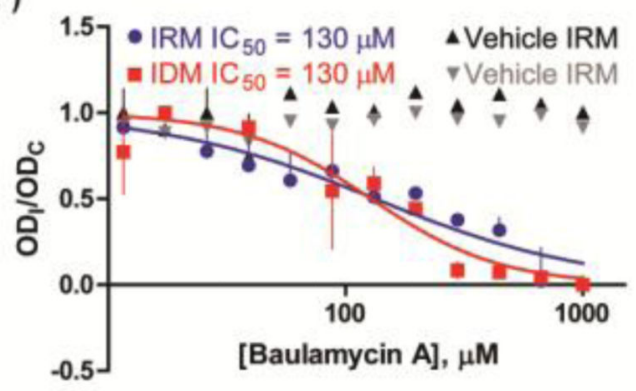

H)

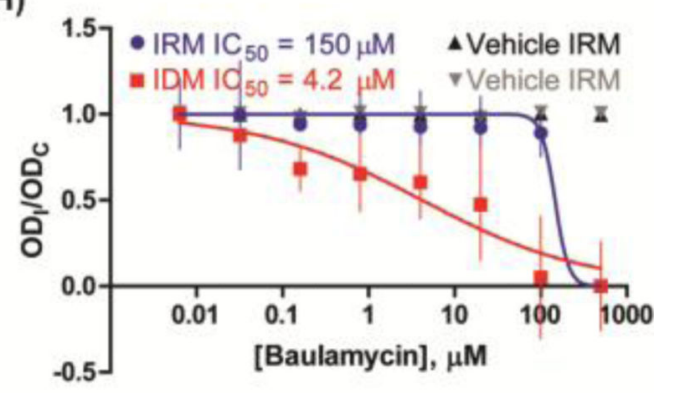

Figure 6.

(A-C) In vitro bioactivities against purified enzyme recorded for BmcA and BmcB against the NIS synthetase (A) SbnE, (B) AsbA, or (C) AsbB. (D-H) BmcA inhibition against live cultures of microbial strains (D) S. aureus (Newman), (E) B. anthracis (Sterne 34F2), F) MRSA (USA 300), G) S. flexneri (BS103), or (H) E. coli (MC 1061) in iron-depleted (IDM) or iron-rich (IRM) media. The y-axis represents a comparison of the optical densities of 
inhibitor- $\left(\mathrm{OD}_{\mathrm{I}}\right)$ and DMSO control-treated $\left(\mathrm{OD}_{\mathrm{C}}\right)$ cultures. Assays were conducted in duplicate due to the current limited availability of the baulamycins. 


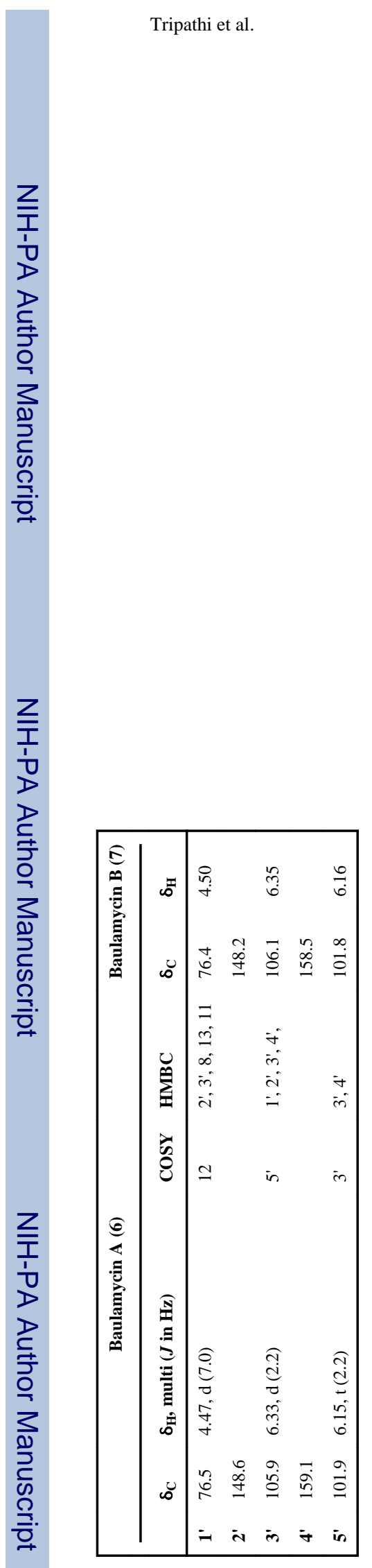

$J$ Am Chem Soc. Author manuscript; available in PMC 2015 January 29. 


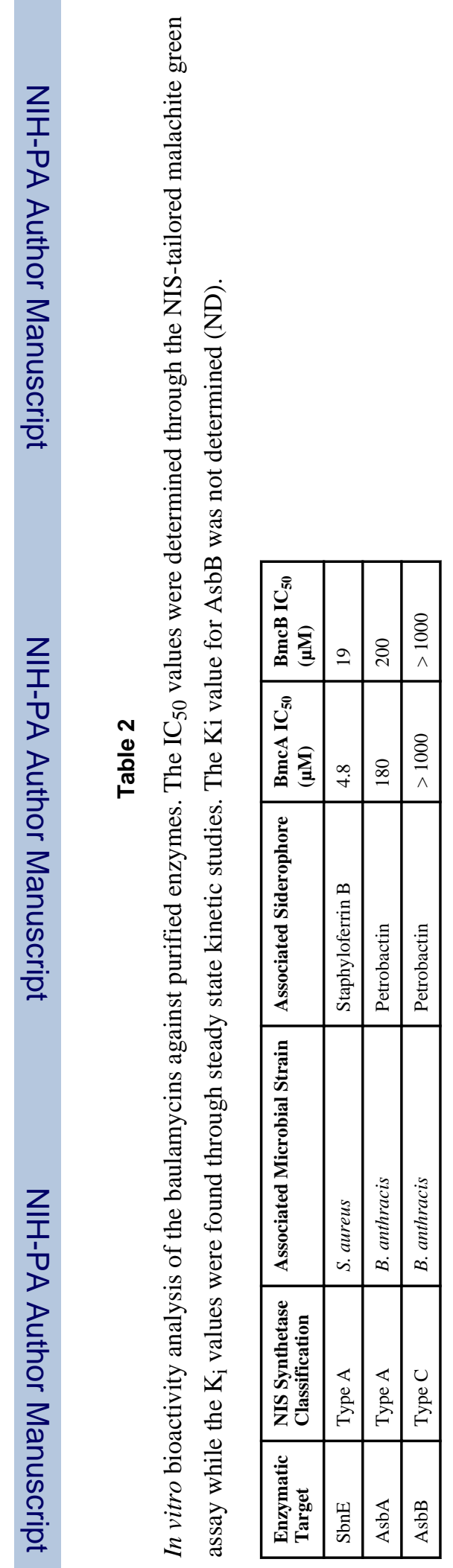

$J$ Am Chem Soc. Author manuscript; available in PMC 2015 January 29. 


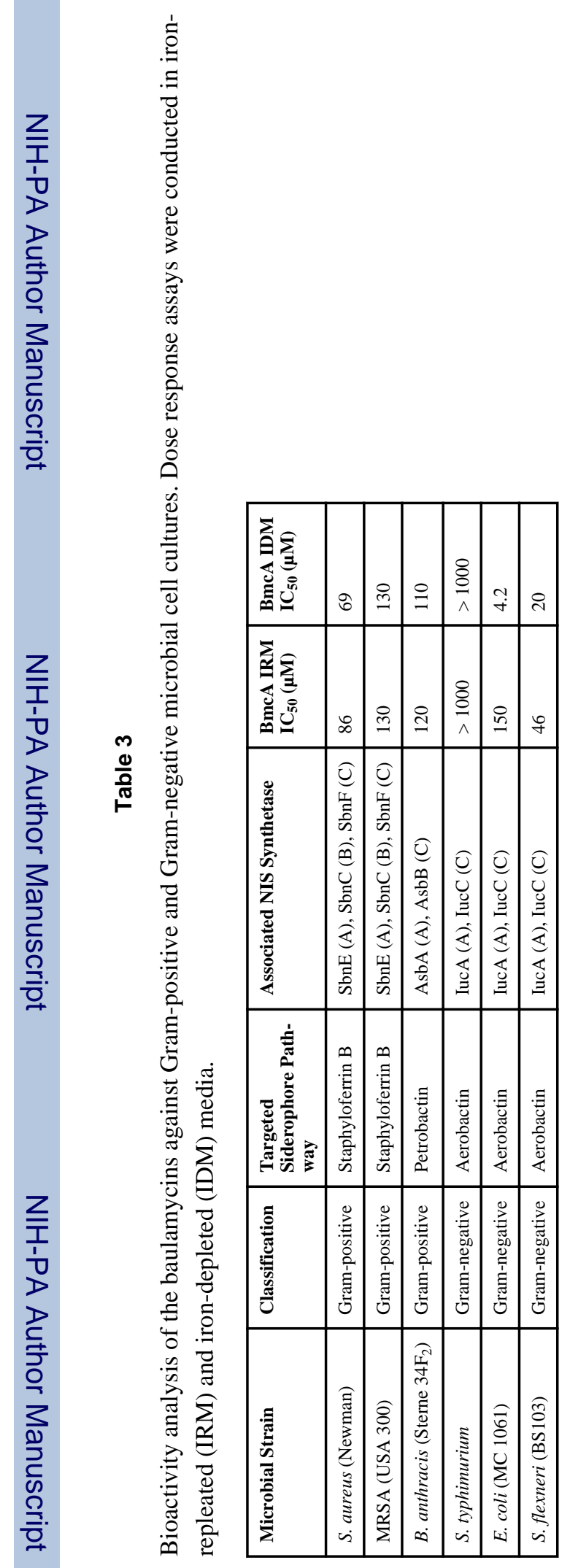

$J$ Am Chem Soc. Author manuscript; available in PMC 2015 January 29. 